\title{
Personality and relational determinants of following physicians' instructions in patients with mixed diabetic foot syndrome
}

\author{
Michal Goran Stanišić', Teresa Rzepa², Magdalena Kucun, Lidia Cierpialkowska ${ }^{3}$ \\ 'Department of General and Vascular Surgery, Poznan University of Medical Sciences, Poland \\ ${ }^{2}$ University of Social Sciences and Humanities, Department of Poznan, Poland \\ ${ }^{3}$ Institute of Psychology, Adam Mickiewicz University in Poznan, Poland
}

\begin{abstract}
Introduction. The aim of study was to verify of the connection between personality and relational factors, and obeying physicians' orders by the patients with diabetic foot syndrome (DFS).

Material and methods. The impact of the following factors was assessed: therapeutic alliance between the physician and the patient, health locus of control, stress coping style, image of one's disease, and demographic data. The study involved thirty (30) type 2 diabetes patients, treated in outpatients clinics, threatened with limb amputation due to the concurrent mixed diabetic foot syndrome.
\end{abstract}

Results. The statistical analysis revealed a correlation between following physicians' instructions and the strength of the therapeutic alliance and the task-oriented stress coping style.

Conclusions. The obtained research results may be the basis for any subsequent modification of treatment modalities of the diabetic foot syndrome.

Key words: diabetic foot syndrome, following physician's orders/instructions, doctor-patient relationship

Acta Angiol 20I5; 21, 3: 83-86

\section{Introduction}

Diabetes has been given the dishonourable name of a civilisation disease and is generally considered to be a serious problem. Diabetes occurrences have been more and more numerous, affecting younger and younger people, it is often genetically conditioned, and hard to prevent and treat. People asked if they have diabetes often reply: "Not yet".

In accordance with the classical approach to the doctor-patient relationship, a medical consultation in the case of type 2 diabetes complicated with diabetic foot syndrome is a conversation of a specialist and a layman. The physician's task is to interview the patient, diagnose the disease and provide the patient with appropriate instructions and recommendations which should be followed by the patient. In this model, there are discrete disproportions in the area of decision-making and taking over the responsibility. It is the physician who makes the decision and tries to persuade the patient to follow his or her advice, while the patient is expected to take responsibility and be consistent in its implementation. This regards not only simple instructions such as regular taking of medicine, but also more complicated recommendations such as changing the lifestyle (e.g. radical modification of the diet, regular physical exercises). As a decision on being obedient and following the physician's instructions depends on numerous factors, it is hard to anticipate which patient will take them in and implement effectively.

It is known that patients are more eager to follow physicians' orders when they assess their illness as

Address for correspondence: Michal Goran Stanišić, Department of General and Vascular Surgery, Poznan University of Medical Sciences, Dluga I/2, 6I-848 Poznan, e-mail: goranm@gazeta.pl 
a serious one, they know it may recur, observe its aggravation and when they are convinced of the treatment efficacy [I]. Other decisive factors include the patient's sense of personal responsibility for own health and his or her conviction that they participate in making decisions on the treatment process. This is because a possibility of making a decision leads to a conviction of exerting control over the illness, which is particularly important in the case of chronic diseases such as diabetes. Moreover, a patient must pay heed to possible and very serious complications that include large blood vessels and heart diseases, and cerebral stroke. Other complications regard small blood vessels which, if untreated, may lead to damaging nerves (neuropathy), eyes (retinopathy) and kidneys (nephropathy). Sensory nerves damage may result in a dangerous condition: diabetic foot syndrome. When any injury goes unnoticed and its healing is impeded, the wounds may be so serious that amputation becomes necessary [2].

The research studies done so far have indicated that $20 \%$ of type 2 diabetics did not control their blood glucose levels, and $70 \%$ of them did not do the recommended physical exercises [3]. Other research studies have shown that patients tended to keep check-up appointments and (equally often) followed the recommendations regarding diet and medicines; however, they least often followed advice on changing the lifestyle [4]. It was also found out that the general percentage of following simple as well as complex instructions given by physicians was quite low for diabetics and ranged from 50 to $10 \%$ [5]. Besides, the percentage is hard to estimate, as patients often conceal the truth, and physicians prefer to believe in such reassuring though distorted information provided by patients, as this helps reinforce the doctors' conviction on their persuasiveness. However, another research study proves that following physicians' instructions responsibly has a better effect than changing the diabetes treatment plan [6]. In this process, positive relations between the patient and the physician are of particular importance. They may be modelled on the psychotherapeutic relations established by psychologists and their patients, based on cooperation, partnership and trust. It has been shown that close relations with the specialist have a positive impact on the course and effects of treatment, and that patients who are dissatisfied with those relations follow the physicians' orders less diligently or don't follow them at all [7].

\section{Material and methods}

The purpose of the research study was verification of the correlation between following physicians' instructions and selected personality factors (i.e. stress coping style, health locus of control, image of one's disease) and the relational factors (patient-physician relation), i.e. the quality of the therapeutic alliance established by both parties to the alliance. The study involved research tools that enable measurement of specified factors, namely:

- Rating scale for following physicians' instructions - the list of 12 requirements to be met by diabetics so as to prevent complications. The scale was developed in 200 I by Agnieszka Makar and extended to include one more question;

- Therapeutic Alliance Questionnaire - developed by Horvath (198I) [8] and adapted to the Polish conditions by Cierpialkowska and Kubiak (2009) [9], applied to measure the alliance between the physician and the patient or between a patient and a psychotherapist;

- Disease-Related Appraisals Scale — developed by Steuden and Janowski (2002) [10] and applied to measure subjective perception of the disease situation. It includes 47 questions and is divided into 7 subscales: "Threat", "Injustice”, "Benefit”, "Obstacle”, "Challenge”, "Value” and "Meaning";

- Coping Inventory for Stressful Situations (CISS) - developed by Szczepaniak, Strelau and Wrzesniewski (1996) [I I]. It consists of 48 statements referring to behaviours shown by people in difficult situations (e.g. in case of a serious disease). The answers help identify 3 coping styles: Task-oriented (TO), Emotion-oriented (EO) and Avoidance-oriented (AO), while AO includes Distraction (DI) and Social Diversion (SD);

- Multidimensional Health Locus of Control (MHLC) - adapted by Juczynski (200I) [12], and developed by Wallston, Wallston and DeVellis (1978) [13]. The scale consists of 18 statements comprising 3 subscales: Internal health locus of control (Int.), External health locus of control (Ext.), Fate, luck or chance (FLC).

The study involved 30 patients ( 23 men and 7 women) with type 2 diabetes, threatened with limb amputation due to the concurrent mixed diabetic foot syndrome. Additionally, demographic data were recorded, on the basis of which it was found that the subjects of the study were from 52 to 79 years old, and the average age was 65 years. As for education, the largest group (I I persons) had completed secondary education, 2 patients - primary education, 3 - technical, 8 - vocational and 6 - tertiary education. Five patients lived in villages, $4-$ in towns with populations of under $10 \mathrm{~K}, 8$ - in towns with $10-50 \mathrm{~K}$ inhabitants, and 13 - in a city with a population exceeding $50 \mathrm{~K}$ inhabitants. Two subjects were diagnosed with the disease when they were in the 20-29 age group, five — in the 30-39 age group, seven — in the 40-49 age 
Table I. Results of statistical descriptive analysis $(\mathrm{N}=30)$

\begin{tabular}{|l|c|c|c|c|c|c|}
\hline Scale & Subscales & Mean & Median & Standard deviation & Min. & Max. \\
\hline Rating scale for following physicians' instructions & None & 37.97 & 39 & 6.911 & 18 & 45 \\
\hline Therapeutic Alliance Questionnaire & None & 69.07 & 68.5 & 12.202 & 43 & 84 \\
\hline Disease-Related Appraisals Scale & Threat & 33.63 & 36 & 7.43 & 14 & 40 \\
\hline & Injustice & 21.93 & 21.5 & 7.865 & 10 & 35 \\
\hline & Benefit & 18.1 & 18 & 5.454 & 9 & 33 \\
\hline & Obstacle & 26.87 & 28 & 9.73 & 10 & 40 \\
\hline & Challenge & 23.8 & 24 & 5.061 & 11 & 30 \\
\hline & Value & 18.47 & 19 & 5.532 & 8 & 28 \\
\hline CISS & Meaning & 19.9 & 21 & 4.992 & 5 & 25 \\
\hline & TO & 57 & 39.5 & 9.329 & 35 & 71 \\
\hline & EO & 46.1 & 46 & 11.333 & 25 & 65 \\
\hline & AO & 46.53 & 45.5 & 9.376 & 28 & 69 \\
\hline & DI & 19.3 & 18.5 & 5.528 & 11 & 32 \\
\hline MHLC & SD & 18.3 & 18 & 3.554 & 12 & 25 \\
\hline & Int. & 28.47 & 28 & 3.98 & 22 & 36 \\
\hline & Ext. & 25.77 & 26.5 & 6.055 & 14 & 36 \\
\hline & FLC & 19.67 & 17 & 8.049 & 7 & 36 \\
\hline
\end{tabular}

Table 2. Correlation between following the physicians' instructions and stress coping style

\begin{tabular}{|l|l|c|c|c|c|c|}
\hline \multicolumn{2}{|c}{ Variables } & TO & EO & AO & DI \\
\hline \multirow{2}{*}{ Following the instructions } & Pearson correlation coefficient & $0.492^{*}$ & -0.104 & 0.018 & -0.193 & 0.284 \\
\cline { 2 - 8 } & Significance (2-tailed) & 0.006 & 0.583 & 0.925 & 0.308 & 0.129 \\
\hline & $\mathrm{N}$ & 30 & 30 & 30 & 30 & 30 \\
\hline
\end{tabular}

"Correlation is significant at the 0.01 level (2-tailed)

group, nine - in the 50-59 age group, six - in the 60-69 age group and one in the 70-79 age group. Nine patients had been ill for a period from I to 9 years, II - from 10 to 19 years, 7 - from 20 to 29 years, and single patients from 30 to 39 , from 40 to 49 and from 50 to 59 years.

\section{Results}

In general, the subjects of the study highly rated their therapeutic alliance with the attending physician and equally highly - their following his or her instructions (Table I). They usually perceived their illness as a threat and an obstacle. They recognised that their coping style was task-oriented and that their health locus of control was mainly internal.

The statistical analysis showed significant correlations between following physicians' instructions and the quality of the therapeutic alliance and the task-oriented
Table 3. Correlation between following the physicians' instructions and quality of therapeutic alliance

\begin{tabular}{|l|l|c|}
\hline \multicolumn{2}{|l|}{ Variables } & Alliance \\
\hline $\begin{array}{l}\text { Following the } \\
\text { instructions }\end{array}$ & $\begin{array}{l}\text { Pearson correlation } \\
\text { coefficient }\end{array}$ & $0.477^{*}$ \\
\hline & Significance (2-tailed) & 0.008 \\
\hline & $\mathrm{N}$ & 30 \\
\hline
\end{tabular}

"Correlation is significant at the $0.0 \mathrm{I}$ level (2-tailed)

stress coping style. The obtained positive correlations mean that type 2 diabetes patients, threatened with limb amputation due to the concurrent mixed diabetic foot syndrome, follow the physicians' instructions when they apply the task-oriented stress coping style (Table 2) and when they experience a strong therapeutic alliance with the physicians (Table 3). However, no correlation was found between following the physicians' instruc- 
tions and health locus of control, image of one's disease and demographic data.

\section{Discussion}

The research study was aimed at verifying the correlation between following the physicians' instructions and selected personality and relational factors such as: stress coping style, health locus of control, image of one's disease. Additionally, the correlation with demographic data was verified. The statistical analysis confirmed existence of two correlations. The first one is a correlation between following the physicians' instructions and the quality of therapeutic alliance, which means that the more positively the patients perceive the relations with the physician, the more willingly they follow the physician's instructions. This finding confirms the earlier conclusions from the quoted studies, and also indicates the high importance of the relational aspect in the process of type 2 diabetes and diabetic foot treatment. Especially in the case of patients with a concurrent risk of limb amputation due to the diabetic foot syndrome, it is vital that they follow the physician's instructions in a responsible and consistent manner.

The other finding regards the correlation between following the physicians' instructions and stress coping style. It turned out that this requirement was met by the task-oriented style (TO). Not only the specialist literature, but also common sense and experience tell us that being affected by a disease is usually perceived as a stressful situation which must be overcome in the most effective way. If a patient perceives treatment as an implementation of a vital task leading to health improvement, he or she gains enormous motivation to act, and thus he or she follows their physician's orders willingly and responsibly.

\section{Conclusions}

The presented research results may be applied in streamlining treatment of diabetic foot patients, as they have shown a strong correlation between the relational factor and patients' following their physicians' instructions. Therefore, it is advisable to establish positive, friendly and trust-based relations between a patient and a physician - especially in the case of patients threatened with limb amputation due to the concurrent mixed diabetic foot syndrome.

\section{References}

I. Heszen-Niejodek I (1992) Lekarz i pacjent. Badania psychologiczne. Universitas, Kraków.

2. Heltzel P (2004) Cukrzyca. Dom Wydawniczy REBIS, Poznań.

3. Morowatisharifabad MA, Mahmoodabad SS, Baghianimoghadam $\mathrm{MH}$, Tonekaboni NR (2010) Relationships between locus of control and adherence to diabetes regimen in a sample of Iranians. Int J Diabetes Dev Ctries; 30: 27-32. doi: 10.4103/09733930.60009 .

4. Tykarski A, Brzezinska U (2005) Terapia hipotensyjna a przestrzeganie zaleceń. Nadciśnienie Tętnicze; 9: 217-227.

5. Ley P, Whitworth MA, Skilbeck CE et al (1976) Improving doctor-patient communication in general practice. Coll Gen Pract; 26: 720-724.

6. Clark M (2004) Adherence to treatment in patients with type 2 diabetes. J Diabet Nursing; 8.

7. Jakubowska-Winecka A, Włodarczyk D (2007) Psychologia w praktyce medycznej. Wydawnictwo PZWL, Warszawa.

8. Horvath A (198I) Client and Therapist forms. The Working Alliance Inventory (WAI).

9. Cierpiałkowska L, Kubiak J (2010) Niespecyficzne czynniki leczące a efektywność terapii alkoholików. Nauka; 2: 89-III.

10. Steuden S, Janowski K (2002) Schorzenia psychodermatologiczne. Przegl Dermatol; 89: 175-183.

II. Szczepaniak P, Strelau J, Wrześniewski K (1996) Diagnoza stylów radzenia sobie ze stresem za pomocą polskiej wersji kwestionariusza CISS Endlera i Parkera. Przegl Psychol; 39: 187-210.

12. Juczyński Z (200I) Wielowymiarowa skala umiejscowienia kontroli zdrowia - MHLC. Narzędzia pomiaru w promocji i psychologii zdrowia. Pracownia Testów Psychologicznych Polskiego Towarzystwa Psychologicznego, Warszawa: 79.

13. Wallston KA, Wallston BS, DeVellis R (1978) Development of the multidimensional health locus of control (MHLC) scales. Health Education Monographs; 6: 160-170. 